University of Nebraska - Lincoln

DigitalCommons@University of Nebraska - Lincoln

U.S. Environmental Protection Agency Papers

U.S. Environmental Protection Agency

2009

\title{
Foodweb modeling for polychlorinated biphenyls (PCBs) in the Twelvemile Creek Arm of Lake Hartwell, South Carolina, USA
}

\author{
Brenda Rashleigh \\ National Exposure Research Laboratory, U.S. Environmental Protection Agency, 960 College Station Road, \\ Athens, GA 30605, USA \\ M. Craig Barber \\ National Exposure Research Laboratory, U.S. Environmental Protection Agency, 960 College Station Road, \\ Athens, GA 30605, USA \\ David M. Walters \\ National Exposure Research Laboratory, U.S. Environmental Protection Agency, 26 West MLK Drive, \\ Cincinnati, $\mathrm{OH} 45268$, USA
}

Follow this and additional works at: https://digitalcommons.unl.edu/usepapapers

Part of the Civil and Environmental Engineering Commons

Rashleigh, Brenda; Barber, M. Craig; and Walters, David M., "Foodweb modeling for polychlorinated biphenyls (PCBs) in the Twelvemile Creek Arm of Lake Hartwell, South Carolina, USA" (2009). U.S. Environmental Protection Agency Papers. 10.

https://digitalcommons.unl.edu/usepapapers/10

This Article is brought to you for free and open access by the U.S. Environmental Protection Agency at DigitalCommons@University of Nebraska - Lincoln. It has been accepted for inclusion in U.S. Environmental Protection Agency Papers by an authorized administrator of DigitalCommons@University of Nebraska - Lincoln. 


\title{
Foodweb modeling for polychlorinated biphenyls (PCBs) in the Twelvemile Creek Arm of Lake Hartwell, South Carolina, USA
}

\author{
Brenda Rashleigh ${ }^{a, *}$, M. Craig Barber ${ }^{a}$, David M. Walters ${ }^{b, 1}$ \\ a National Exposure Research Laboratory, U.S. Environmental Protection Agency, 960 College Station Road, Athens, GA 30605, USA \\ b National Exposure Research Laboratory, U.S. Environmental Protection Agency, 26 West MLK Drive, Cincinnati, OH 45268, USA
}

\section{A R T I C L E I N F O}

\section{Article history:}

Received 5 January 2008

Received in revised form

25 August 2008

Accepted 5 September 2008

Published on line 22 October 2008

\section{Keywords:}

Bioaccumulation

AQUATOX

Lake Hartwell

$\mathrm{PCB}$

Sensitivity analysis

\begin{abstract}
A B S T R A C T
PCBs from the Sangamo-Weston Superfund Site near Clemson, South Carolina, USA, were released into the Twelvemile Creek Arm of Lake Hartwell until the early 1990s. Monitoring data have shown that while PCB concentration in sediments declined since 1995, PCB concentrations in fish have remained elevated, e.g., largemouth bass (Micropterus salmoides) concentrations have ranged from 5 to $10 \mathrm{ppm}$. The EPA aquatic ecosystem model AQUATOX was applied to this system to better characterize foodweb dynamics that lead to biomagnification of PCBs. The model was calibrated with observed fish biomass data. Simulated PCB loading over a 12-year period provided a reasonable fit to observed PCB data in fish. The model demonstrated that contaminated labile detritus loaded to the system was incorporated into the foodweb rather than deposited, thereby maintaining the PCB concentrations in fish while concentrations in the sediment declined. A dominant PCB pathway was from detritus to daphnia to shad to largemouth bass. Fish PCB concentrations showed moderate sensitivity to toxicant parameters; model runs incorporating uncertainty in these parameters predicted recovery (<2 ppm PCB) for all species in the range of years from 2008 to 2013. The high sensitivity of the model to parameters related to growth strongly affected $P C B$ concentrations in fish and should be considered in future AQUATOX applications.
\end{abstract}

Published by Elsevier B.V.

\section{Introduction}

Historical releases of polychlorinated biphenyls (PCBs) from the Sangamo-Weston plant in Pickens, South Carolina, have led to bioaccumulation in fishes in downstream waters. The Sangamo-Weston plant manufactured capacitors and discharged an estimated cumulative amount of 181.4 MT of PCBs from 1955 to 1977 into Town Creek, a tributary of Twelvemile Creek (U.S. EPA, 1994). Contamination of sediment and biota in Twelvemile Creek and in the Twelvemile Creek Arm (TCA) of Lake Hartwell is well documented. Studies in 1976 by the South
Carolina Department of Health and Environmental Control and the U.S. EPA found fishes in Lake Hartwell to be contaminated at levels above the safe tolerance level at that time (5.0 ppm) (U.S. EPA, 1987), and fish consumptions advisories were issued for portions of the lake. Concentrations of PCBs in the sediments of the reservoir were also elevated (Dunnivant et al., 1989).

Remediation of the Sangamo-Weston site and satellite dumping grounds was completed in 1997; the downstream area is being treated with Monitored Natural Recovery, which relies on continued deposition of clean sediment to cap

\footnotetext{
* Corresponding author. Tel.: +1 706355 8148; fax: +1 7063558104 .

E-mail address: Rashleigh.Brenda@epa.gov (B. Rashleigh).

${ }^{1}$ Current address: US Geological Survey, Fort Collins Science Center, 2150 Centre Avenue, Fort Collins, CO 80526, USA. 0304-3800/\$ - see front matter. Published by Elsevier B.V. doi:10.1016/j.ecolmodel.2008.09.007
} 
contaminated sediments (U.S. EPA, 1994; Battelle, 2003; U.S. EPA, 2004a). PCBs in sediments and aquatic fauna have been monitored since 1995 to gauge the effectiveness of Monitored Natural Recovery in lowering PCB concentrations in sediments and aquatic fauna (Georgia DNR, 2006). Brenner et al. (2004) demonstrated that PCB concentrations in TCA sediments in 2001 and 2002 were in the range of $1 \mathrm{ppm}$, the recovery goal for sediments (U.S. EPA, 1994). The recovery goal for PCBs in fish tissue is $2.0 \mathrm{ppm}$, which is the current federally specified level for fish consumption (U.S. EPA, 1994). Although some tissue data show that concentrations are declining in some species over time, data for largemouth bass (Micropterus salmoides), a primary sport-fish in the TCA, show that PCB levels remain above the recovery goal (Brenner et al., 2004).

In order to understand the patterns of contamination in Lake Hartwell fish, it is necessary to understand the sources and pathways for PCBs into fishes at higher trophic levels and the residence times of PCBs in the Lake Hartwell foodweb. Foodweb models can contribute valuable information on biotic processing of contaminated material, persistence of PCBs in the aquatic environment, and potential lag times in natural recovery. The Lake Hartwell foodweb was previously investigated by Brockway et al. (1995), and simulations beginning in 1991 were conducted by Bechtel Engineering Inc. (1993), which estimated that mean PCB concentrations in largemouth bass fillets would drop below the recovery limit by approximately 2001. Here we applied the AQUATOX model to the TCA, in order to provide updated simulations using more recent data. AQUATOX is a simulation model for aquatic systems that predicts the fate of various pollutants and their effects on the ecosystem (U.S. EPA, 2004b). AQUATOX was favorably reviewed in a recent evaluation of integrated eutrophication, fate, and effects models by Koelmans et al. (2001). Integrated models such as these allow the user to include feedback mechanisms, identify dominant processes, and develop hypotheses about ecosystem functioning (Koelmans et al., 2001).

For this study, our objectives were to (1) apply the AQUATOX model to the TCA to provide an updated simulation and future forecasts; (2) explore the sensitivity of the model and how this relates to future predictions; and (3) identify important pathways of contaminants to higher trophic levels (i.e., fishes) and possible mechanisms driving the ongoing high levels of PCBs observed in fishes. Such an understanding will enable managers to better identify sources and pathways of ongoing PCB contamination and to predict recovery times. Also, this is to our knowledge the first published account of an AQUATOX application to a contaminated system outside of the model validation reports (U.S. EPA, 2000), as well as the first published sensitivity analysis of AQUATOX that includes fish, so this application provides useful information for other potential model users.

\section{Methods}

\subsection{Model set-up}

The AQUATOX model (Release 3.1) was parameterized and applied to the TCA region of Lake Hartwell in South Carolina, the section of the reservoir that is of primary interest due

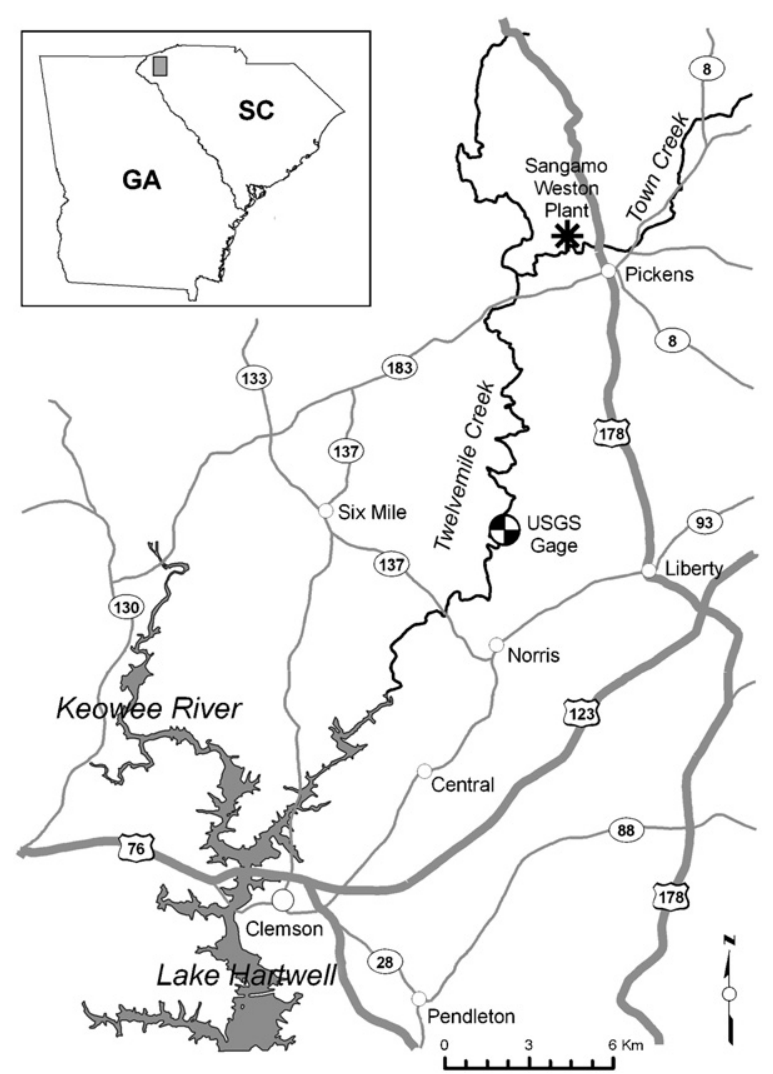

Fig. 1 - Location of the study area. The source of PCBs in the system was the Sangamo-Weston plant, located along Town Creek, a tributary to Twelvemile Creek. The AQUATOX model was applied to the Twelvemile Creek Arm of Lake Hartwell from the USGS gage downstream to the confluence with the Keowee River.

to PCB releases upstream (Fig. 1). Lake Hartwell is a reservoir along the Georgia/South Carolina border created by the Hartwell Dam on the Savannah River. The study reach is a 20.4$\mathrm{km}$ stretch of the TCA, with the upstream boundary at the U.S. Geological Survey (USGS) gage \#02186000 (Twelvemile Creek near Liberty, SC) and the downstream boundary between the TCA and lower Lake Hartwell, at the confluence with the Keowee River. The study reach was selected to coincide with the reach used for recent hydrodynamic modeling on the TCA (RMT, 1999), which provided values for reservoir depth and volume. Parameters for light, wind, evaporation, and temperature required by AQUATOX were taken from available literature data (Table 1). The photoperiod is determined by AQUATOX based on the latitude of the USGS gage. The model can be adjusted to allow the system to stratify; however, initial model runs showed no sensitivity to this option, so it was not used in the final analysis.

Flow values at the USGS gage were available at the USGS National Water Information System website (http://nwis. waterdata.usgs.gov/nwis/nwis) only until September 2001, so a regression with a nearby gage with highly correlated flow (Eighteen Mile Creek above Pendleton, SC, $\rho=0.90, p<0.0001$ ) was used to generate the missing values. The AQUATOX model determines outflow to maintain a constant volume. Mean 
Table 1 - Input data used to parameterize the AQUATOX model for Lake Hartwell TCA.

\begin{tabular}{|c|c|c|}
\hline Parameter & Value & Source and notes \\
\hline Surface area & $30,381 \mathrm{~m}^{2}$ & RMT (1999) \\
\hline Depth & Maximum: $13.7 \mathrm{~m}$; mean: $4.3 \mathrm{~m}$ & RMT (1999) \\
\hline Light & Mean: 361; range: 261-461 Ly/d & $\begin{array}{l}\text { National Renewable Energy Laboratory (1994), for Augusta, GA, 1961-1990, } \\
\text { flat-plate collector with } 0^{\circ} \text { tilt }\end{array}$ \\
\hline Evaporation & $37.6 \mathrm{in} . /$ year & $\begin{array}{l}\text { US Army Corps of Engineers (1996), mean of } 20 \text { years of data for } \\
\text { Savannah River Basin }\end{array}$ \\
\hline Wind & $2.9 \mathrm{~m} / \mathrm{s}$ & $\begin{array}{l}\text { US Army Corps of Engineers (1996), mean of monthly values (1961-1990) } \\
\text { for the National Weather Service Station, Augusta, GA airport }\end{array}$ \\
\hline Water temperature & Mean: $19^{\circ} \mathrm{C}$; range: $11-27^{\circ} \mathrm{C}$ & $\begin{array}{l}\text { Bechtel Engineering Inc. (1993), represented as a sine curve, repeated } \\
\text { each year }\end{array}$ \\
\hline $\mathrm{pH}$ & 7.0 & $\begin{array}{l}\text { STORET (US EPA Storet database, http://www.epa.gov/storet/); mean of } 12 \\
\text { samples from USGS gage (2002), sd =0.3 }\end{array}$ \\
\hline Oxygen & $9.9 \mathrm{mg} / \mathrm{L}$ & STORET, mean of 12 samples from USGS gage (2002), S.D. $=1.6$ \\
\hline Ammonia & Inflow: $0.05 \mathrm{mg} / \mathrm{L}$ & STORET for USGS gage; non-point source load adjusted to $25 \mathrm{~g} / \mathrm{d}$ \\
\hline Nitrate & Inflow: $0.2 \mathrm{mg} / \mathrm{L}$ & STORET for USGS gage; non-point source load adjusted to $5000 \mathrm{~g} / \mathrm{d}$ \\
\hline Phosphate & Inflow: $0.1 \mathrm{mg} / \mathrm{L}$ & STORET for USGS gage; non-point source load adjusted to $200 \mathrm{~g} / \mathrm{d}$ \\
\hline
\end{tabular}

values for inflow dissolved oxygen, $\mathrm{pH}$, nitrate, ammonia, and phosphate measured were taken from the U.S. EPA STORET database for the USGS gage location and used as constant input (Table 1). We adjusted non-point source loads for nitrate, ammonia, and phosphate so that mean concentrations in the lake were in agreement with measured values.

Default parameters for detrital processes supplied by the AQUATOX model were used because these are considered appropriate for most systems (U.S. EPA, 2004C), except that the maximum degradation rate of labile detritus was reduced from its default of 0.29 day $^{-1}$ to 0.15 day $^{-1}$ (Webster and Benfield, 1986). Input detritus was specified as $1.3 \mathrm{mg} / \mathrm{L}$ dry weight of organic matter (Huffstetler and Carroll, 1992). The total amount of detritus is divided into four compartments in AQUATOX: particulate refractory and labile organic detritus, and dissolved refractory and labile detritus. For Lake Hartwell, detritus was partitioned as 30\% particulate versus $70 \%$ dissolved, and $60 \%$ refractory versus $40 \%$ labile (D. Park, Eco Modeling, pers. comm., 2005). The model required initial estimates for refractory and labile sedimented detritus; for Lake Hartwell, the estimates were set at 12 and $6 \mathrm{~g} / \mathrm{m}^{2}$ dry weight, which are the values that the model adjusts to after transient initial dynamics.

\subsection{Foodweb representation}

Conceptually, PCBs are loaded to the system through water and detritus, taken up into lower levels of the foodweb, and transferred to higher levels through feeding interactions. The AQUATOX model requires the user to provide a foodweb depicting the tropic interactions among the biological components in the system. The foodweb used to represent the TCA is shown in Fig. 2. Four species of invertebrates were included: mayfly; Daphnia sp. (water flea); Chironomid sp. (midge larvae); and the predatory invertebrate, Chaoborus sp. (phantom midge larvae). We represented the dominant fish species in the lake: largemouth bass, bluegill (Lepomis macrochirus), and shad (Dorosoma cepedianum, Dorosoma petenense-these two species of shad were combined, due to their ecological similarities). We generally accepted the default trophic interactions in AQUATOX for these biota (U.S. EPA, 2004b) but also considered diet data from Leidy and Plotsky (1980) for invertebrates and Leidy and Jenkins (1977) for fish to establish trophic interactions (Fig. 2).

Fishes are the main focus of this modeling effort because they are potentially consumed by humans (U.S. EPA, 1994). The foodweb was simplified to focus on the dominant species in the reservoir even though additional species such as carp or striped bass could affect the dynamics of the components that were modeled (Bechtel Engineering Inc., 1993). We recognize that the foodweb in Fig. 2 is missing additional members, and the nature and level of interactions is also uncertain. Bartell et al. (2003) have discussed the need for ecological risk assessment models to balance the realism of an assessment model with the usefulness of model outputs for the needs of each particular application. For this application, we concentrated on those with reasonable data available.

To parameterize each fish species, we took temperature response slope, optimum and maximum temperature, maximum consumption, Specific Dynamic Action (SDA), and respiration parameters from the Wisconsin Bioenergetics model (Hanson et al., 1997); shad were represented using herring

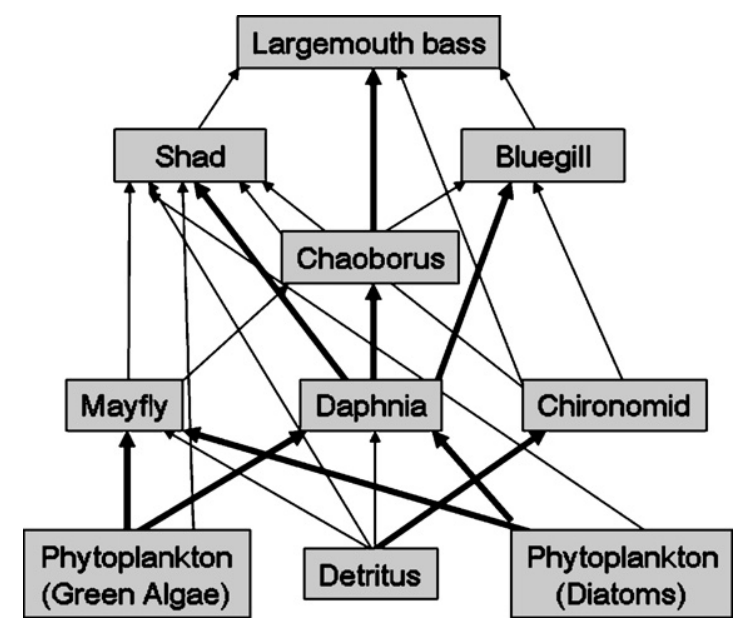

Fig. 2 - Diagram of the Lake Hartwell TCA foodweb simulated in AQUATOX. Thick lines indicate strong interactions ( $>30 \%$ of the diet). 
feeding parameters and bluegill temperature parameters (Table 2). Egestion fraction was set at 0.3 for feeding on invertebrates and algae, 0.4 for feeding on fish, and 0.5 for feeding on detritus. Daily fish mortality rates were taken from Leidy and Jenkins (1977) (Table 2). Fish species spawn one time per year, with a gamete:biomass ratio of 0.05 and gamete mortality of 0.1 day $^{-1}$ for all species. For invertebrates, Leidy and Plotsky (1980) was used as the source for invertebrate mortality rates, respiration rates, maximum consumption, and maximum temperature; and optimum temperature and temperature response were taken from the AQUATOX library and references therein. We adjusted half-saturation parameters for fish species in calibration, as described below. A nominal loading of $0.00001 \mathrm{~g} / \mathrm{m}^{2}$ was assumed for all biota in order to promote stability of the simulation.

\subsection{Biomass calibration}

The model was run for the years 1995-2006, which is the time range for which PCB data are available, and predicted fish biomass data was calibrated to existing fish biomass values measured by the Georgia Department of Natural Resources (GADNR). The GADNR fish biomass data used in calibration was collected with cove Rotenone sampling at three locations in Lake Hartwell in mid-August of 1978, 1981, 1984, 1987, 1990, and 1995. We calculated mean biomass for species by pooling data across sites and years (Table 2). These values are in line with carrying capacity estimates given by Leidy and Jenkins (1977) for shad, sunfish, and black bass for southeastern reservoirs (Table 2). Fish biomass in AQUATOX was initialized with data collected by the GADNR. A wet:dry biomass ratio of 5 was used to convert dry weight biomass predicted by AQUATOX to wet weight values measured by GADNR (Barber, 2003).

To calibrate the model, values of half-saturation parameters for all three fish species were adjusted so that mean biomass for each fish species in mid-August stabilized in the range of the values measured by the GADNR. Half-saturation was chosen as a calibration parameter because parameters controlling biomass - consumption, respiration, and half-saturation - were related to one another, and consumption and respiration were better known than half-saturation (Hanson et al., 1997). Biomass values predicted by AQUATOX were assumed to be in agreement with measured values if two conditions were met: (1) total biomass for the three fish species were within the range of measured total biomass in every year and (2) no significant difference between the mean predicted biomass and the observed mean biomass of each species, using a student's t-test. A time series of fish biomass with a greater sampling frequency would be more desirable for calibration, but this type of data is rarely available.

\subsection{Representation of PCBs}

PCBs were modeled as total PCB (tPCB), which is the unit used for the recovery level for Lake Hartwell, so this was the most useful modeling endpoint from the management perspective. Although the field data were reported as mixtures (Aroclors), it would have been difficult to simulate individual mixtures, since different Aroclors occurred in different years: only 1254 was reported in 1995; Aroclor 1260 was reported starting in 1996 but half of the values were below detection levels; and Aroclor 1242 was first reported in 2001. Also, different Aroclors were reported from the sediment. Aroclor 1254 was the only Aroclor reported from the system in 1995, the dominant mixture in all years, and within the dominant homolog group in the Lake Hartwell system (Brockway et al., 1995), so parameters for this mixture were used for the model: a molecular weight of $328 \mathrm{~g} / \mathrm{mol}$, logoctanol-water partition coefficient $\left(K_{\text {ow }}\right)$ of 6.5 , and Henry's law constant of $2.0 \times 10^{-3}$ (Agency for Toxic Substances and Disease Registry, 2000).

We relied on available measured data to set the PCB concentration in water. In 1991, PCBs were undetected in the study area at detection limits ranging from 0.49 to $2.0 \mu \mathrm{g} / \mathrm{L}$ and in 1992, PCBs were undetected at detection limits of 1.2 or $1.3 \mu \mathrm{g} / \mathrm{L}$

Table 2 - Biota characteristics used in the AQUATOX model application to Lake Hartwell.

\begin{tabular}{|c|c|c|c|c|c|c|c|}
\hline \multirow[t]{2}{*}{ Parameters } & \multicolumn{4}{|c|}{ Invertebrates } & \multicolumn{3}{|c|}{ Fish } \\
\hline & Chironomid & Mayfly & Daphnia & Chaoborus & Shad & Bluegill & $\begin{array}{l}\text { Largemouth } \\
\text { bass }\end{array}$ \\
\hline $\begin{array}{l}\text { Elimination rate constant } \\
\qquad\left(k_{2}, 1 \mathrm{~d}^{-1}\right)\end{array}$ & 0.015 & 0.0122 & 0.0243 & 0.0112 & 0.0009 & 0.0014 & 0.0010 \\
\hline Lipid fraction (wet weight) & 0.05 & 0.05 & 0.05 & 0.05 & 0.06 & 0.05 & 0.04 \\
\hline Half-saturation (mg/L) & 0.43 & 1.7 & 1.0 & 0.045 & 2.55 & 1.35 & 0.515 \\
\hline $\begin{array}{l}\text { Maximum consumption } \\
\text { (g/gd) }\end{array}$ & 0.19 & 0.1 & 1.2 & 0.25 & \multicolumn{3}{|c|}{ Based on Hanson et al. (1997) } \\
\hline $\begin{array}{l}\text { Optimum, maximum } \\
\text { temperature }\left({ }^{\circ} \mathrm{C}\right)\end{array}$ & 15,29 & 18,35 & 26,34 & 23,37 & 27,36 & 27,36 & $27.5,37$ \\
\hline Temperature response & 2.4 & 1.6 & 2.4 & 1.6 & 2.3 & 2.3 & 2.65 \\
\hline Mortality rate $\left(1 \mathrm{~d}^{-1}\right)$ & 0.001 & 0.001 & 0.002 & 0.01 & 0.0020 & 0.0016 & 0.0008 \\
\hline Mean wet weight (g) & 0.0075 & 0.02 & 0.0006 & 0.02 & 60 & 40 & 500 \\
\hline Respiration $\left(1 \mathrm{~d}^{-1}\right)$ & 0.035 & 0.02 & 0.15 & 0.029 & \multicolumn{3}{|c|}{ Based on Hanson et al. (1997) } \\
\hline $\begin{array}{l}\text { Southeastern reservoirs } \\
\text { ( } \mathrm{g} / \mathrm{m}^{2} \text { wet weight) }\end{array}$ & Not available & & & & 3.6 & 2.1 & 1.1 \\
\hline $\begin{array}{l}\text { GADNR mean biomass } \\
\text { (S.D.) (g/m² wet weight) }\end{array}$ & Not available & & & & $5.1(3.1)$ & $2.3(0.9)$ & $0.8(0.2)$ \\
\hline
\end{tabular}


(Bechtel Engineering Inc., 1993). Battelle (2003) collected nine water samples in Twelvemile Creek in 2001 in which PCB concentrations ranged from below the detection limit (which was not provided) to $0.19 \mu \mathrm{g} / \mathrm{L}$, with a value of $0.05 \mu \mathrm{g} / \mathrm{L}$ measured upstream of the gage. We set initial condition of PCB in lake water to $0.05 \mu \mathrm{g} / \mathrm{L}$ and assumed no inflow of PCB in water.

AQUATOX assumes that all PCB in sediment is associated with the detritus, which was modeled in AQUATOX as organic matter. The initial PCB concentration of sedimented detritus in the lake was calculated from data reported by Brenner et al. (2004): $2 \mathrm{mg}$ PCB per kg dry sediment, divided by $0.03 \mathrm{~kg}$ total organic carbon (TOC) per kg dry sediment, divided by 1.9 (standard AQUATOX conversion from TOC to organic matter) $=35 \mathrm{mg} \mathrm{PCB} / \mathrm{mg}$ sediment organic matter. $\mathrm{PCB}$ load for inflow detritus was set based on yearly observed sediment concentrations at the sample site directly upstream of the USGS gage (Site SD002); the AQUATOX model conducts linear interpolation between the yearly values.

Initial levels of PCB in phytoplankton and benthic invertebrates were set at the values to which preliminary model runs equilibrated. Elimination rates for fish and invertebrates were calculated based on Barber (2003):

$k_{2}=\frac{C \times \text { wet weight }^{-0.197}}{\text { lipid fraction } \times K_{\text {ow }}}$,

where $C=445$ for fish and $C=890$ for invertebrates. Estimated values for lipid fraction and mean wet weight, generally based on AQUATOX defaults, are given in Table 2.

\subsection{Model assessment}

Concentrations of PCBs predicted for fish were compared to measured values from station SV-107, located approximately $5.5 \mathrm{~km}$ upstream of the confluence with the Keowee River, which we considered representative of TCA (Georgia DNR, 2006). The U.S. EPA Region 4 collected fish by electrofishing and gill netting in April of each year, and fillets were analyzed using PCB Aroclor Method 8082 (U.S. EPA, 1994). Initial toxicant levels in fish were specified based on existing data from the SV107 site from the initial study year, 1995 (Georgia DNR, 2006). Measured values were in units of total PCBs in fillets (ppm wet weight); we used a factor of 0.75 to convert whole-body concentrations predicted by AQUATOX to equivalent fillet concentrations (Amrhein et al., 1999, calculated from mean values reported in Table 1). Predicted values were compared to measured values in terms of means and standard deviations; mean error and mean percent error to measure bias in the model predictions; root mean square error and mean absolute error, which measure predictive accuracy of the model and should be as small as possible (Power, 1993); and $r^{2}$ to measure the tendency of predicted and observed values to vary together linearly.

\subsection{Analysis of the TCA system}

We conducted a sensitivity analysis in order to identify the parameters that the model was most sensitive to; that is, where model outcome shows a relatively large change in response to a smaller change in that parameter. The analysis was conducted by sequentially increasing individual physical/chemical, fish, invertebrate, algae, and toxicant parameters by $10 \%$ and recording the percent change in ending PCB concentration for the three fish species. Sensitivity to fish biomass was also tracked because PCB concentration is strongly dependent on it. We recognize that this approach to sensitivity is simplified; additional sensitivity analyses should consider parameter interactions (Tang et al., 2007).

The calibrated AQUATOX model for TCA was run to year 2030 to predict when PCB concentrations for all fishes fall below the recovery level of $2 \mathrm{ppm}$. We focused on the recovery of largemouth bass, the fish that showed the slowest decline in PCB concentrations. The 12-year flow regime was repeated to represent future flow. Future input detritus was set at a constant $0.12 \mathrm{ppm}$, which was the mean in the stream between the gage and the source based on 21 samples in 2003-2004. Five uncertainty runs - representing uncertainty in the most sensitive physical/chemical, fish, invertebrate, algae, and toxicant parameters - were conducted to establish bounds $( \pm 1$ S.D.) on the predicted recovery date established in the future forecast. We used the default uncertainty analysis procedure in AQUATOX, where parameter values are selected with Latin hypercube sampling from a normal distribution with a standard deviation equal to $60 \%$ of the mean for a set of 20 runs.

We then analyzed daily rates of PCB movement, which AQUATOX calculates for each process associated with each state variable as the magnitude of the flow in or out of the pool (in $\mu \mathrm{g} / \mathrm{L}$ ) divided by the magnitude of the pool (U.S. EPA, 2004c). Rates were used to identify the dominant PCB pathways in the system.

\section{Results}

\subsection{Assessment of results for fish biomass and PCB concentrations}

When parameters were adjusted in calibration to the values given in Tables 1 and 2, predicted total fish biomass for mid-August of each year fell within the range of measured values. The range of modeled biomass was 5.1-9.0; the range of measured biomass was from 3.9 to $13.9 \mathrm{~g} / \mathrm{m}^{2}$. There was no significant difference between the mean measured GADNR biomass and predicted biomass for any species: (t-test results for shad: $p=0.58$, bass: $p=0.78$, and bluegill: $p=0.16)$. There was some variation in fish biomass across the years due to variation in flow-high flow or large flow events increased washout of prey items, which reduced fish growth and biomass.

The fit between observed PCB concentrations in fish and values predicted by the model is relatively good for all species (Fig. 3, Table 3). Predicted data generally fell within one standard deviation of the observed data, when a range was available-in some cases (e.g., bluegill in most years) data for only a single fish was available so the range could not be compared. Mean error and percent mean error measure the bias in the model predictions, which should be close to zero; mean error was $<1$ and percent error was $<20 \%$ for all fish. The negative mean error for shad and bluegill indicated that the model 


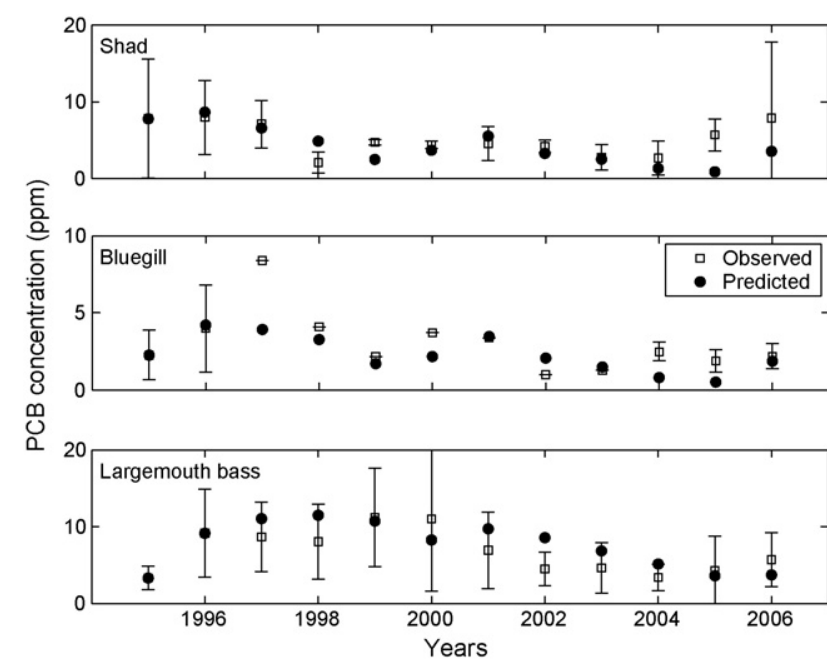

Fig. 3 - Predicted and observed total PCB fillet concentrations (wet-weight) over twelve years in three fish species for Lake Hartwell TCA. Observed values are concentrations averaged by fish species measured at a central sample site in TCA (SV-107) in April of each year.

is under-predicting the observed values. The lowest $r^{2}$-value occurred for shad (0.33). For shad, and also bass, it appeared that the predicted pattern followed the observed with a time lag of 1-2 years (Fig. 3). Also, the model was not able to reproduce the sharp increases in observed data (e.g., 125\% increase from 1998 to 1999 for shad, 111\% increase from 1996 to 1997 for bluegill).

\subsection{Sensitivity analysis}

Table 4 shows the sensitivity of fish PCB concentration to a $10 \%$ increase in input variables for all tested variables for which fish PCB sensitivities were $\geq 1$. Biomass sensitivity is also shown in Table 4 in order to support the interpretation of patterns in PCB concentration, which often reflect the biomass sensitivities. PCB concentration in largemouth bass generally showed higher sensitivity to increased input variables than that of shad or bluegill. The highest sensitivity of PCB in largemouth bass occurred in response to optimum temperature for the bass. The increase in optimum temperature shifted the species' temperature response curve with respect to the temperature regime, such that more days were further from the species' optimum temperature. This resulted in a strong decline in biomass (-91\%), which caused an increase in PCB concentration (65\%). PCB in largemouth bass was also highly sensitive to the optimal temperature for shad, its most contaminated prey item-the loss of shad biomass $(-100 \%)$ led to a decline in the bass PCB concentration $(-33 \%)$, as bass switched to less toxic prey.

The set of parameters to which the bass PCB concentration was sensitive ( $\geq 10 \%)$ was dominated by maximum consumption, optimum temperature, half-saturation, and respiration for fish and invertebrates. These changes altered biomass of different compartments, and the resulting changes in PCB concentrations were determined by foodweb interactions. The only environmental variables within this sensitivity range were $\mathrm{NO}_{3}$, which stimulated growth of phytoplankton that served as food for invertebrates and fishes and led to growth dilution of PCB in fish; and inflow water, which increased washout of the prey items, reduced biomass, and therefore increased PCB concentration. PCB concentrations in all three fish species increased moderately (8-10\%) in response to increased PCB octanol-water coefficient $\left(\log K_{\text {ow }}\right)$, amount of contaminated input detritus, and level of PCB in input detritus.

The sensitivity of PCB in bass was $<10 \%$ for several parameters, including growth parameters for additional species and SDA and mortality for most species (Table 4). For this set of parameters, sensitivity of PCB in shad and bluegill was also $<10 \%$, except for the sensitivity of PCB in shad to parameters for respiration (27\%) and half-saturation (13\%) and PCB in bluegill to respiration (19\%). Increases in these parameters decreased fish biomass and increased PCB concentration in the fish, and therefore in bass, the top predator. Sensitivities $<1 \%$ not shown in Table 4 included PCB molecular weight and Henry's law coefficient, physical/chemical variables $\left(\mathrm{pH}\right.$, light, oxygen, suspended solids, and $\left.\mathrm{CO}_{2}\right)$, additional

Table 3 - Model performance statistics comparing observed and predicted total PCB fillet concentrations (ppm) for four fish species from the Lake Hartwell TCA for 1995-2006 ( $N=12)$.

Model performance statistics

Fish species

\begin{tabular}{lccc} 
& Shad & Bluegill & Largemouth bass \\
\cline { 3 - 4 } Mean total PCB concentration & & & 2.32 \\
$\quad$ Predicted & 4.28 & 3.08 & 7.64 \\
$\quad$ Observed & 5.17 & & 6.74 \\
Standard deviation of total PCB concentration & & 1.17 & 3.03 \\
$\quad$ Predicted & 2.47 & 1.95 & 2.84 \\
$\quad$ Observed & 2.12 & -0.75 & 0.90 \\
Mean error & -0.90 & -0.13 & 0.18 \\
Mean percent error & -0.11 & 1.57 & 2.27 \\
Root mean square error & 2.23 & 1.02 & 1.88 \\
Mean absolute error & 1.63 & 0.47 & 0.53 \\
$r^{2}$ & 0.33 & &
\end{tabular}


Table 4 - Sensitivity of mean biomass and mean PCB concentration for fish species in AQUATOX for Lake Hartwell in response to a $10 \%$ increase in input parameters ( $\max =$ maximum, opt $=$ optimum).

Parameters (listed in order of Bass PCB Biomass PCB concentration sensitivity)

\begin{tabular}{|c|c|c|c|c|c|c|}
\hline & & & & \\
\hline & Shad & Bluegill & Bass & Shad & Bluegill & Bass \\
\hline Temperature (opt): Bass & 57 & 60 & -91 & 3 & 0 & 65 \\
\hline Temperature (opt): Shad & -100 & -7 & 35 & 535 & 2 & -33 \\
\hline Respiration: Chironomid & -18 & -17 & -87 & -1 & -5 & 29 \\
\hline Temperature (opt): Daphnia & 12 & 14 & -33 & 5 & 6 & 24 \\
\hline Consumption (max): Daphnia & -19 & -30 & 72 & -7 & -6 & -19 \\
\hline Respiration: Daphnia & 10 & 45 & -22 & 4 & 3 & 16 \\
\hline Consumption (max): Mayfly & -4 & -79 & -73 & 3 & 8 & 16 \\
\hline Respiration: Bass & 27 & 25 & -47 & 1 & 0 & 16 \\
\hline Consumption (max): Shad & -17 & -89 & 300 & -16 & 0 & 15 \\
\hline Half-saturation: Daphnia & 10 & 34 & -20 & 3 & 3 & 14 \\
\hline $\mathrm{NO}_{3}$ & -23 & -52 & 342 & -17 & -10 & -12 \\
\hline Water Inflow & -7 & -7 & -32 & 5 & 6 & 12 \\
\hline Consumption (max): Bass & -43 & -38 & 72 & -2 & 1 & -12 \\
\hline Temperature response slope: Daphnia & -7 & -23 & -19 & 2 & 4 & 11 \\
\hline Consumption (max): Bluegill & -69 & 381 & 284 & -6 & -2 & -11 \\
\hline PCB in input detritus & 0 & 0 & 0 & 10 & 10 & 10 \\
\hline Photosynthetic rate (max): Green algae & -40 & -36 & 203 & -5 & 1 & -9 \\
\hline Temperature response slope: Bass & 23 & 22 & -37 & 1 & 0 & 9 \\
\hline PCB log octanol-water partition coefficient & 0 & 0 & 0 & 8 & 10 & 9 \\
\hline Detritus loading & 3 & -3 & 30 & 8 & 9 & 8 \\
\hline SDA: Daphnia & 5 & 15 & -13 & 2 & 2 & 8 \\
\hline Half-saturation: Bass & 25 & 24 & -40 & 1 & 0 & 8 \\
\hline Temperature (opt): Chironomid & -4 & -6 & -64 & -1 & -3 & 8 \\
\hline Half-saturation: Shad & -93 & 45 & -82 & 13 & 2 & -7 \\
\hline Temperature (opt): Chaoborus & 6 & 8 & -8 & 1 & 3 & 7 \\
\hline Respiration: Shad & -96 & 48 & -84 & 27 & 3 & -6 \\
\hline Temperature response slope: Shad & -91 & 42 & -81 & 8 & 2 & -6 \\
\hline Temperature (opt): Diatoms & -29 & -24 & 135 & -3 & 2 & -6 \\
\hline Consumption (max): Chironomid & -50 & -39 & 263 & -2 & 6 & -6 \\
\hline SDA: Chironomid & 0 & -1 & -51 & 0 & -2 & 5 \\
\hline SDA: Bass & 8 & 7 & -15 & 0 & 0 & 5 \\
\hline Half-saturation: Chironomid & 1 & -2 & -51 & 0 & -2 & 5 \\
\hline $\mathrm{NH}_{3}$ and $\mathrm{NH}_{4}{ }^{+}$ & 2 & -3 & 90 & -4 & -3 & -5 \\
\hline Respiration: Chaoborus & -1 & -9 & -5 & 1 & 3 & 4 \\
\hline Respiration: Bluegill & 15 & -91 & -27 & 1 & 19 & 4 \\
\hline Temperature (opt): Green algae & 3 & 22 & -63 & -1 & -5 & 4 \\
\hline Temperature response slope: Chaoborus & 5 & 9 & -7 & 1 & 2 & 4 \\
\hline Mortality: Shad & -22 & 14 & -34 & -1 & 1 & -4 \\
\hline Saturating light: Diatoms & -14 & -12 & 63 & -1 & 1 & -3 \\
\hline Half-saturation: Bluegill & 12 & -81 & -23 & 1 & 5 & 3 \\
\hline SDA: Chaoborus & -1 & -5 & -4 & 0 & 2 & 3 \\
\hline SDA: Shad & -41 & 24 & -52 & 5 & 1 & -3 \\
\hline Temperature (opt): Bluegill & 10 & -70 & -19 & 1 & -10 & 3 \\
\hline Consumption (max): Chaoborus & 6 & 48 & 7 & -2 & -3 & -2 \\
\hline Wind & 0 & 0 & -4 & -2 & -3 & -2 \\
\hline SDA: Bluegill & 6 & -47 & -13 & 0 & 3 & 2 \\
\hline Mortality: Chaoborus & -1 & -3 & 0 & 0 & 1 & 2 \\
\hline Mortality: Chironomid & 1 & 1 & -28 & 0 & -1 & 2 \\
\hline Water temperature & -6 & 51 & 34 & 9 & -1 & 1 \\
\hline Temperature response slope: Bluegill & 5 & -37 & -10 & 1 & -3 & 1 \\
\hline Temperature (max): Shad & 11 & -11 & 32 & -1 & -1 & 1 \\
\hline Half-saturation: Chaoborus & -2 & -2 & 2 & 0 & 1 & 1 \\
\hline Mortality: Green algae & -1 & -3 & -14 & 0 & 0 & 1 \\
\hline Temperature (max): Bass & -4 & -4 & 7 & 0 & 0 & -1 \\
\hline Photosynthetic rate (max): Diatoms & 5 & 9 & -40 & -1 & -5 & 0 \\
\hline Saturating light: Green algae & -1 & -2 & -26 & 0 & -1 & 0 \\
\hline
\end{tabular}


Table 5 - Fate of PCB in the simulated Lake Hartwell system.

\begin{tabular}{|c|c|c|}
\hline PCB in compartment & Gain (\%) & Loss (\%) \\
\hline Largemouth bass & Diet (0.1) & Mortality (0.1), depuration (0.1) \\
\hline Bluegill & $\operatorname{Diet}(0.3)$ & Mortality (0.2), depuration (0.1) \\
\hline Shad & $\operatorname{Diet}(0.3)$ & Mortality (0.2), depuration (0.1) \\
\hline Chironomid & $\operatorname{Diet}(1.8)$ & Depuration (1.2), mortality (0.5), predation (0.1) \\
\hline Chaoborus & Diet (5.1), gill uptake (0.2) & Washout (3.3), mortality (1.0), depuration (1.0) \\
\hline Mayfly & Diet (0.6) & depuration (1.1), mortality (0.1) \\
\hline Daphnia & Diet (9.4), gill uptake (0.3) & Predation (4.2), washout (3.3), depuration (1.5) \\
\hline Diatoms & Uptake (38) & Depuration (20), predation (8.0), mortality (6.5) \\
\hline Green algae & Uptake (42) & Depuration (20), predation (9.7), mortality (6.5) \\
\hline Dissolved labile detritus & Formation $^{\mathrm{a}}$ (12.1), load (1.5) & Decomposition (10.9), washout (3.3) \\
\hline Dissolved refractory detritus & Load (2.2), formation (1.6) & Washout (3.2), colonization (2.7) \\
\hline Particulate labile detritus & Formation (21.9), colonization (3.0) & $\begin{array}{l}\text { Decomposition (10.9), predation (8.5), washout } \\
\text { (3.3), sedimentation (3.2) }\end{array}$ \\
\hline Refractory particulate detritus & Formation (5.7), load (1.0) & $\begin{array}{l}\text { Washout (3.2), sedimentation (3.2), colonization } \\
\text { (2.7), predation (1.7) }\end{array}$ \\
\hline Sedimented labile detritus & Formation (9.7), colonization (4.7), sedimentation (2.4) & Decomposition (14.4), predation (2.6) \\
\hline Sedimented refractory detritus & Formation (2.5), sedimentation (0.4) & Colonization (2.7), predation (0.1), burial (0.1) \\
\hline Water & Depuration (55), decomposition (52) & $\begin{array}{l}\text { Algal sorption (95), volatilization (8.0), washout } \\
\text { (3.4), gill sorption ( } 0.3 \text { ) }\end{array}$ \\
\hline
\end{tabular}

Dominant gains and losses are listed for each compartment, which are calculated as the magnitude of the flow in or out of the pool ( $\mu \mathrm{g} /(\mathrm{L} \mathrm{d})$ ) divided by the magnitude of the pool $(\mu \mathrm{g} / \mathrm{L})$, expressed as a percent $(100 \times)$.

a Formation includes mortality, excretion, defecation, and gamete loss.

biotic parameters for invertebrates, and all initial conditions, including toxicant in all compartments.

\subsection{Future predictions and uncertainty}

A future model run showed that largemouth bass, which showed the slowest decline in PCB concentrations compared to other fishes, should reach recovery level ( $2 \mathrm{ppm})$ in the fall of 2011. When uncertainty was introduced into the most sensitive physical/chemical, fish, invertebrate, or algae parameters, the predicted fish biomass spanned several orders of magnitude, outside the range of observed biomass, so we could not obtain useful predictions for PCB concentrations under these scenarios. When uncertainty was introduced into the most sensitive toxicant parameters $\left(\log \mathrm{K}_{\mathrm{ow}}\right.$ and PCB detrital loading), there was no effect on fish biomass, and the range $( \pm 1$ S.D.) for predicted recovery time for largemouth bass was from the summer of 2008 to the summer of 2013.

\subsection{Rates and pathways}

Analysis of the rates of PCB movement among model compartments is summarized in Table 5. For all fishes and invertebrates, diet uptake exceeded gill uptake; the ratio of gill:diet uptake was in the range of $5 \%$, which is consistent with similar studies (Barber, 2003). Fish and invertebrates lost PCB through mortality and depuration; invertebrates also lost PCB through washout and predation. For algae, the dominant gain was uptake and the dominant loss was depuration. The dominant PCB gain for dissolved and particulate detritus occurred through morality, defecation, excretion, and gamete loss from other model compartments. For particulate labile detritus, the largest detrital pool, PCB was lost to mainly to decomposition (11\%) and ingestion (9\%), rather than sedimentation (3\%) (Table 5). PCBs in sedimented detritus accumulated through formation and sedimentation; colonization was the dominant loss of PCB from the refractory pool (and a gain to the labile pool), and decomposition was the dominant loss from the labile pool. PCB released to the water through decomposition and depuration was quickly taken up by algae.

The PCB in the largemouth bass comes mostly from its diet-most likely obtained from Chaoborus, the most dominant prey item, and shad, the most contaminated and second most dominant prey item (Fig. 2). Contamination in shad and Chaoborus is mostly via their diets, both of which are dominated by daphnia. Daphnia also receives its contamination via its diet, which consists of detritus and algae. Sensitivity analysis of daphnia, largemouth bass, and shad PCB concentrations to sequential increases in each of the daphnia diet items showed that highest sensitivity occurred in response to PCB in the labile particulate detritus in the daphnia diet.

\section{Discussion}

This application of AQUATOX to the TCA allowed us to meet our objective of providing an updated simulation with future forecasts. As expected, differences in toxicant concentrations among species were due to differences in diet (Luk, 2000), and PCB concentration in largemouth bass declined most slowly, due to their large size and carnivorous diet. There was reasonable agreement of the observed PCB concentrations, although it may be difficult to match observed data based on low sample numbers with high variability. Certain aspects of the measured PCB could not be reproduced, particularly sharp increases-it is possible that these are related to irregular flushing of sediment collected behind upstream dams (Dunnivant et al., 1989), which was not represented in the model. One difficulty in representing PCB dynamics with AQUATOX is that elimination of the chemical is represented as a constant flow; that is, fecal excretion is not explicitly 
represented, which could lead to an inaccurate representation of elimination. Also, the equations AQUATOX uses for modeling contaminant bioaccumulation in compartments are a mixture of compartmental and individual processes, which, while being dimensionally correct, makes it difficult to represent compartmental concentrations by manipulating only individual-based uptake and elimination rates.

Despite the model's complexity, it is still a simplification of the actual site in many ways. For example, algorithms used by AQUATOX to describe dietary and gill chemical are largely empirically based and may not reflect the current mechanistically based understanding of these processes (see for example, Barber, 2003; Arnot and Gobas, 2004; Kelly et al., 2004). Likewise, lethal and sublethal effects were not represented here; AQUATOX does provide this capability but concentrations in the fishes were well below toxic levels (Mayer and Ellersieck, 1986). Uncertainty is associated with feeding relationships, which could be considered in future analysis (Preziosi and Pastorok, 2008). Intra-specific differences in terms of size and sex, which were not considered here, can also affect PCB uptake in fishes (Bremle and Larsson, 1998; Madenjian et al., 1998). The approach used here assumed both temporal simplification, ignoring yearly differences in temperature, and spatial simplification, ignoring that spatial heterogeneity has been demonstrated in sediment concentrations across the lake (Dunnivant et al., 1989; Sivey and Lee, 2007). The representation of spatial heterogeneity in a system can increase realism (Pastorok et al., 2001; von Stackelberg et al., 2002). Additionally, movement of species in and out of the study area was not considered, and this could affect the PCB concentrations in the system (Bayne et al., 2002). Future work can address these issues of uncertainty in terms of model structure and model architecture.

In the exploration of sensitivity of fish PCB concentration, our second objective, we found that it mirrored biomass sensitivity, where an increase in biomass was accompanied by a decrease in PCB concentration due to growth dilution. Observed fish biomass has been relatively stable since the 1960s, so the sensitivity may be a property of the model rather than a representation of reality. Bass PCB concentration was highly sensitive to selected parameters: a $10 \%$ parameter increase resulted in a sensitivity of $>10 \%$ for 15 parameters, four of which were $>20 \%$. In contrast, Simon (1999) showed that an FGETS model applied to this same system had equivalent sensitivities of $<10 \%$ for all parameters tested. van Nes et al. (2002) showed $\leq 20 \%$ sensitivity for all selected parameters within PISCATOR, a multi-species individual-based fish model. PCB concentration in bass was most sensitive to optimal temperature, which is consistent with Sourisseau et al. (2008), who showed that predators' highest sensitivity in an AQUATOX application for two artificial streams was also optimum temperature. Model users should be aware of the potentially high sensitivity of higher trophic groups. In reality, temperature across Lake Hartwell is heterogeneous and fish may move to pockets of suitable temperature, so it is unlikely that temperature has such a large effect on the fishes in this ecosystem (unless these pockets correlate with levels of contamination). Based on the high sensitivity of fish PCB concentration to maximum consumption, respiration, half-saturation parameters, it appears to be a property of the model that the feeding parameters are "balanced" to predict a stable biomass for fish and invertebrates. Both this study and Sourisseau et al. (2008) found that the highest sensitivities for algae in AQUATOX were saturating light, optimum temperature, and maximum photosynthetic rate.

Our results showed that sensitivity of fish PCB concentration to $\log K_{\text {ow }}$ was moderate, and sensitivities to $\mathrm{PCB}$ molecular weight and Henry's law constant were low, compared to sensitivities of other parameters in the model. These three parameters would be used in AQUATOX to represent different congeners. PCBs would be most accurately represented as congeners, since these differ in their chemical properties and their toxicological effects (Cleverly, 2005), however, the low to moderate sensitivity in these parameters indicates that a representation of different congeners in this system would most likely show a similar result to the one found here for total PCBs. The moderate sensitivity and uncertainty in fish PCB concentration in response to the toxicity of input detritus allowed us to make useful predictions for this system, assuming that the biomass is accurately represented.

Our third objective was to identify important pathways of contaminants to higher trophic levels (i.e., fishes) and possible mechanisms driving the ongoing high levels of PCBs observed in fishes. An interesting finding with respect to PCBs in the Lake Hartwell system is that PCB loading appears to occur through input of contaminated detritus that is taken up in the foodweb. We attribute this result to the process by which contaminated detritus entering the system is consumed by invertebrates and fish rather than being incorporated in the sediment. A dominant pathway was via transfer of PCB from detritus to daphnia to shad to largemouth bass. This is consistent with the results of Stapleton et al. (2001), who found that suspended particulate matter rather than sediment was the main method of exposure for fishes to PCB in Lake Michigan. Likewise, Thomann et al. (1992) found that the dominant pathway of exposure to amphipods in Lake Ontario for a chemical with $\log K_{\text {ow }}$ in the range 5.5-7 was through consumption of particulate organic carbon in the sediment. The concentration of PCB in input detritus for Lake Hartwell is largely unknown. Quantifying the amount, toxicity, and timing of input detritus is critical for understanding the current dynamics of the system.

This modeling analysis provides a better understanding of the system and informs management options. Ecosystem models such as AQUATOX are useful for studying organic pollutants such as PCB, since these pollutants tend to be persistent and present in all environmental phases (Wania and Mackay, 1999). It is particularly useful to have models that represent multiple stressors (Wania and Mackay, 1999; Rose et al., 2003). Such models can provide estimates of the time needed for toxicant concentrations in fish to be reduced below target levels for human health. Knowledge of the time response is important for management, and can influence remediation choices (Gobas et al., 1995). These predictions and estimates could be incorporated into probabilistic risk assessment techniques for the site (Simon, 1999). Additionally, the model could be used in the assessment of future proposed remediation activities, such as upstream dam removal (U.S. EPA, 2004a). Assessment of alternatives and predictive capability are valuable contributions that ecological risk models for 
bioaccumulation can provide to environmental management of aquatic systems (Sharpe and Mackay, 2000).

\section{Acknowledgements}

The authors are grateful for the assistance of Dick Park, Marjorie Wellman, Jon Clough, Earl Hayter, Bob Ambrose, Jim Lazorchak, Marc Mills, Jim Orr, Wayne Garrison, and Craig Zeller. We also thank two anonymous reviewers. This paper has been reviewed in accordance with the U.S. EPA's peer and administrative review policies and approved for publication.

\section{REFERENCES}

Agency for Toxic Substances and Disease Registry, 2000. Toxicological Profile for Polychlorinated Biphenyls (PCBs). US Department of Health and Human Services, Washington, DC

Amrhein, J.F., Stow, C.A., Wible, C., 1999. Whole-fish versus filet polychlorinated biphenyl concentrations: an analysis using classification and regression tree models. Environ. Toxicol. Chem. 18, 1817-1823.

Arnot, J.A., Gobas, F.A.P.C., 2004. A food web bioaccumulation model for organic chemicals in aquatic ecosystems. Environ. Toxicol. Chem. 23, 2343-2355.

Barber, M.C., 2003. A review and comparison of models for predicting dynamic chemical bioconcentration in fish. Environ. Toxicol. Chem. 22, 1963-1992.

Bartell, S.M., Pastorok, R.A., Akçakaya, H.R., Regan, H., Ferson, S., Mackay, C., 2003. Realism and relevance of ecological models used in chemical risk assessment. Hum. Ecol. Risk Assess. 9, 907-923.

Battelle, 2003. Natural Recovery of Persistent Organics in Contaminated Sediments at the Sangamo-Weston/Twelvemile Creek/Lake Hartwell Superfund Site-Phase II. Cincinnati, OH.

Bayne, D.R., Reutebuch, E., Seesock, W.C., 2002. Relative motility of fishes in a southeastern reservoir based on tissue polychlorinated biphenyl residues. N. Am. J. Fish Manage. 22, 122-131.

Bechtel Engineering Inc., 1993. Remedial Investigation Report for the Sangamo Weston Inc./Twelve Mile Creek/Lake Hartwell PCB Contamination Superfund Site Operable Unit Two at Pickens, Pickens County, South Carolina (vol. 2 of 2). Prepared for USEPA by Bechtel Environmental Inc., Contract No. 68-W9-0058.

Bremle, G., Larsson, P., 1998. PCB concentration in fish in a river system after remediation of contaminated sediment. Environ. Sci. Technol. 32, 3491-3495.

Brenner, R.C., Magar, V.S., Ickes, J.A., Foote, E.A., Abbott, J.E., Bingler, L.S., Crecelius, E.A., 2004. Long-term recovery of PCB-contaminated surface sediments at the Sangamo-Weston/Twelvemile Creek/Lake Hartwell Superfund Site. Environ. Sci. Technol. 38, 2328-2337.

Brockway, D.L., Smith, P.D., Barber, M.C., 1995. PCBs in the Aquatic-riparian Zone of the Lake Hartwell Ecosystem, South Carolina. U.S. Environmental Protection Agency, Athens, GA.

Cleverly, D., 2005. Memorandum: Response to Ecological Risk Assessment Forum Request for Information on the Benefits of PCB Congener-specific Analysis. Ecological Risk Assessment Support Center, U.S. Environmental Protection Agency, Cincinnati, OH, ERASC-002F.

Dunnivant, M.F., Polansky, A.L., Elzerman, A.W., 1989. Persistence and distribution of PCBs in the sediments of a reservoir (Lake Hartwell, South Carolina). Bull. Environ. Contam. Toxicol. 43, 870-878.
Georgia DNR, 2006. South Carolina Department of Natural Resources, South Carolina Department of Health and Environmental Control, U.S. Army Corps of Engineers, U.S. Fish and Wildlife Service. Lake Hartwell Restoration and Compensation Determination Plan. http://www.dnr.sc.gov/ lakehartwell/LakeHartwellFinal32006.pdf.

Gobas, F.A.P.C., Z'Graggen, M.N., Zhang, X., 1995. Time response of the Lake Ontario ecosystem to virtual elimination of PCBs. Environ. Sci. Technol. 29, 2038-2046.

Hanson, P.C., Johnson, T.B., Shindler, D.E., Kitchell, J.F., 1997. Fish Bioenergetics Model 3.0. University of Wisconsin Sea Grant College Program, Madison, WI.

Huffstetler, C.J., Carroll, J.H., 1992. Water quality studies: Hartwell Lake 1992 Summary Report. U.S. Army Corps of Engineers Miscellaneous Paper EL-93-21, Savannah, GA.

Kelly, B.C., Gobas, F.A.P.C., McLachlan, M.S., 2004. Intestinal absorption and biomagnification of organic contaminants in fish, wildlife, and humans. Environ. Toxicol. Chem. 23, 2324-2336.

Koelmans, A.A., Van der Heijde, A., Knijff, L.M., Aalderink, R.H., 2001. Integrated modelling of eutrophication and organic contaminant fate \& effects in aquatic ecosystems. Rev. Wat. Res. 35, 3517-3536.

Leidy, G.R., Jenkins, R.M., 1977. The development of fishery compartments and population rate coefficients for use in reservoir ecosystem modeling. Report Y-77-1. United States Department of Interior, Fish and Wildlife Service, Fayetteville, AR.

Leidy, G.R., Plotsky, G.R., 1980. Simulation modeling of zooplankton and benthos in reservoirs: documentation and development of model constructs. Technical Report E-80-4. United States Department of Interior, Fish and Wildlife Service, Fayetteville, AR.

Luk, G.K., 2000. A bioenergetics approach to modeling PCB bioaccumulation in Lake Ontario salmonids. Wat. Qual. Ecosyst. Model. 1, 223-235.

Madenjian, C.P., Noguchi, G.E., Haas, R.C., Schrouder, K.S., 1998. Sexual difference in polychlorinated biphenyl accumulation rates of walleye (Stizostedion vitreum). Can. J. Fish Aquat. Sci. 55, 1085-1092.

Mayer Jr., F.L., Ellersieck, M.R., 1986. Manual of Acute Toxicity: Interpretation and Data Base for 410 Chemicals and 66 Species of Freshwater Animals. U.S. Department of the Interior Fish and Wildlife Service, Washington, DC, 506 pp.

National Renewable Energy Laboratory, 1994. Solar Radiation Data Manual for Flat-plate and Concentrating Collectors. U.S. Department of Energy, Golden, CO.

Pastorok, R.A., Bartell, S.M., Ferson, S., Ginzburg, L.R., 2001. Ecological Modeling in Risk Assessment. Lewis Publishers, Boca Raton, FL, $302 \mathrm{pp}$.

Power, M., 1993. The predictive validation of ecological and environmental models. Ecol. Model. 68, 33-50.

Preziosi, D.V., Pastorok, R.A., 2008. Ecological food web analysis for chemical risk assessment. Sci. Tot. Environ. 406, 491-502.

RMT, 1999. Twelve Mile Creek Sediment Transport Model/Data Collection Report, Sangamo Operable Unit 2, Pickens, County, SC. RMT Inc., Stafford TX.

Rose, K.A., Murphy, C.A., Diamond, S.L., Fuiman, L.A., Thomas, P., 2003. Using nested models and laboratory data for predicting population effects of contaminants on fish: a step toward a bottom-up approach for establishing causality in field studies. Hum. Ecol. Risk Assess. 9, 231-257.

Sharpe, S., Mackay, D., 2000. A framework for evaluating bioaccumulation in food webs. Environ. Sci. Technol. 34, 2373-2379.

Simon, T.W., 1999. Two-dimensional Monte Carlo simulation and beyond: a comparison of several probabilistic risk assessment 
methods applied to a superfund site. Hum. Ecol. Risk Assess. 5, 823-843.

Sivey, J.D., Lee, C.M., 2007. Polychlorinated biphenyl contamination trends in Lake Hartwell, South Carolina (USA): sediment recovery profiles spanning two decades. Chemosphere 66, 1821-1828.

Sourisseau, S., Bassères, A., Périé, F., Caquet, T., 2008. Calibration, validation and sensitivity analysis of an ecosystem model applied to artificial streams. Wat. Res. 42, 1167-1181.

Stapleton, H.M., Masterson, C., Skubinna, J., Ostrom, P., Ostrom, N.E., Baker, J.E., 2001. Accumulation of atmospheric and sedimentary PCBs and toxaphene in a Lake Michigan food web. Environ. Sci. Technol. 35, 3287-3293.

Tang, Y., Reed, P., Wagener, T., van Werkhoven, K., 2007. Comparing sensitivity analysis methods to advance lumped watershed model identification and evaluation. Hydrol. Earth Syst. Sci. 11, 793-817.

Thomann, R.V., Connolly, J.P., Parkerton, T.F., 1992. An equilibrium-model of organic-chemical accumulation in aquatic food webs with sediment interaction. Environ. Toxicol. Chem. 11, 615-629.

US Army Corps of Engineers, 1996. Savannah River Basin Water Control Manual. U.S. Army Engineer District, Savannah, GA.

U.S. Environmental Protection Agency (EPA), 1987. Remedial investigation/feasibility study fact sheet: Sangamo Weston Inc., TwelveMile Creek/Lake Hartwell Site, Pickens County, South Carolina. U.S. Environmental Protection Agency, Region 4, Atlanta, GA.

U.S. EPA, 1994. Superfund Record of Decision: Sangamo-Weston/Twelvemile Creek/Lake Hartwell site,
Pickens, GA: Operable Unit 2. U.S. Environmental Protection Agency, Region 4, Atlanta, GA, EPA/ROD/R04-94/178.

U.S. EPA, 2000. AQUATOX for Windows, Release 1, vol. 3: Model Validation Reports. U.S. Environmental Protection Agency, Office of Water, Washington, DC, EPA-823-R-00-008.

U.S. EPA, 2004a. Five year review report for the Sangamo Weston/Twelvemile Creek/Lake Hartwell Site - Operable Unit 2. Pickens, Pickens County, South Carolina. U.S. EPA Region 4, Atlanta, GA.

U.S. EPA, 2004b. AQUATOX (Release 2) Modeling environmental fate and ecological effects in aquatic ecosystems, vol. 2: Technical documentation. U.S. Environmental Protection Agency, Office of Water, Washington, DC, EPA/823/R-04/002.

U.S. EPA, 2004c. AQUATOX (Release 2) Modeling environmental fate and ecological effects in aquatic ecosystems, vol. 1: Users Manual. U.S. Environmental Protection Agency, Office of Water, Washington, DC, EPA-823-R-04-001.

van Nes, E.H., Lammens, E.H.R.R., Scheffer, M., 2002. PISCATOR, an individual-based model to analyze the dynamics of lake fish communities. Ecol. Model. 152, 261-278.

von Stackelberg, K., Burmistrov, D., Linkov, I., Cura, J., Bridges, T.S., 2002. The use of spatial modeling in an aquatic food web to estimate exposure and risk. Sci. Tot. Environ. 288 97-110.

Wania, F., Mackay, D., 1999. The evolution of mass balance models of persistent organic pollutant fate in the environment. Environ. Pollut. 100, 223-240.

Webster, J.R., Benfield, E.F., 1986. Vascular plant breakdown in freshwater systems. Ann. Rev. Ecol. Syst. 17, 567-594. 